Netra Pal Singh ${ }^{1}$

Manisha Kaushik ${ }^{2}$
JEL: L11

DOI: $10.5937 /$ industrija41-4700

UDK: 621.39:339.13(470) ;005.21:621.39

Professional Paper

\title{
Strategies of Yota (Scartel) - 4G Operator in Russian Federation
}

\author{
Article history \\ Received: 20 September 2013 \\ Sent for revision: 20 October 2013 \\ Received in revised form: 13 November 2013 \\ Accepted: 17 November 2013 \\ Available online: 26 November 2013
}

\begin{abstract}
Russian Federation is one of the high growth markets for telecom services which are expected to reach $\$ 48.5$ billion by 2013 . With the granting of 4G LTE licenses, it is expected that 4G market in Russian Federation will be dominated by four cellular operators, i.e., MTS, Beeline, and MegaFon, Rostelecom along with two new startups, i.e., Osnova Telecom and Red Telecom. In addition, other companies such as Yota, Synterra, COMSTAR, Freshtel etc. are also operating in Russian WiMax \& LTE telecom market to provide similar services. This paper is an attempt to analyze some of the parameters of LTE turn Yota WiMax Telecom Operator in Russian Federation. The paper covers current achievements of Yota, its reach in Russian Federation, its network size \& technology, its services, expansion plans for future, strategies for survival (in question) in a highly competitive market of big companies, and its ultimate fate.
\end{abstract}

Keywords: WiMax, Long Term Evolution (LTE), Yota, Russian Markets, MTS, Beeline, MegaFon, Rostelecom.

\section{Strategija Yota (Scartel) - 4G operatera u Ruskoj Federaciji}

Apstrakt: Ruska Federacija je jedno od brzo rastućih tržišta telekomunikacionih usluga za koje se očekuje da će dostići \$48.5 milijardi dolara tokom 2013. Uz izdavanje dozvola 4G LTE, očekuje se da će $4 G$ tržištem u Ruskoj Federaciji dominirati četiri postojeća mobilna operatera,

1 Management Development Institute Mehrauli Road, Sukhrali, Gurgaon, India, knpsingh@mdi.ac.in

${ }^{2}$ Rukmini Devi Institute of Advanced Studies, India, kaushikmanisha@yahoo.com

Industrija, Vol.41, No.4, 2013 
Singh, N. P., Kaushik, M.: Strategies of Yota (Scartel) - 4G Operator in Russian...

odnosno, MTS, Beeline, i MegaFonu, Rostelecom, zajedno sa dva novoosnovana, odnosno Osnova Telekoma i Red Telekoma. Osim toga, druge kompanije kao što su Yota, Synterra, COMSTAR, Freshtel itd takođe posluju u ruskom ViMak \& LTE telekomunikacionom tržištu sa ciljem da obezbede slične usluge. Ovaj rad je pokušaj da se analiziraju neki od parametara LTE Yota WiMax Telekom operatera u Ruskoj Federaciji. Rad obuhvata aktuelna ostvarenja Yota, njihovog učešća u Ruskoj Federaciji, mreža i tehnologije, usluge, planovi za proširenje u budućnosti, kao i strategije za opstanak na visoko konkurentnom tržištu velikih kompanija.

Ključne reči: WiMax, dugoročna evolucija (LTE), Yota, Rusko tržište, MTS, Beeline, MegaFon, Rostelecom

\section{Introduction}

Yota is the brand name of Scartel LLC. Yota (4G internet-http://www.yota.ru) is the first Russian high-speed wireless network based on Mobile WiMAX technology in a market dominated by top telecom operators such as, MegaFon, Mobile TeleSystems (MTS), Rostelecom and VimpelCom (Beeline). WiMAX technology implemented in Russian markets delivers access speed up to $10 \mathrm{Mbps}$ at any time within the coverage area. The connection is maintained even when user is moving at the speed of $120 \mathrm{~km} / \mathrm{h}$. WiMAX networks of Russian Federation can truly claim the delivery of telecom services at any time and everywhere. It operates in $2.5 \mathrm{GHz}$ spectrum band. Yota started its WiMAX based services in March 2007 (Shaw (2011)).

According to Maistre (2009), 74.9\% of Scartel's parent company, (WiMAX Holding), is owned by a private investment company known as Telconet Capital Limited Partnership, which has made \$300 million available for initial investment to Yota. The remaining $25.1 \%$ is owned by Russian state-owned company Rostechnologii, a Russian state corporation founded as a non-profit Non-Government Oragnization with the goal of supporting domestic technological development (WiMAX Forum (2009)). The Yota invested the $\$ 300$ million cost in installing the initial 1,600 base stations in the cities of Moscow and St Petersburg.

Yota launched its pilot WiMAX services in St Petersburg in November 2008, two months after American telecoms giant Sprint had started to roll out its own services in Baltimore, Maryland. Yota made total investment of $\$ 500$ million. Its sales in the first half of the year, 2010 were \$66million. As per the company sources Yota is already making an operating profit (Economist (2010)). The details of other WiMAX operators in different regions of Russian Federation are compiled in Table 1. Yota has become a big network player in Russian Federations by switching from WiMAX technology to LTE technology 
Singh, N. P., Kaushik, M.: Strategies of Yota (Scartel) - 4G Operator in Russian...

domain and having signed an agreement with four big telecom players for creating 4G networks in Russia (Telecompaper (2011a)). Yota is second LTE wholesale operators after Lightsquared (US). The third LTE wholesale operators in future could be a consortium firm of Kenya or may be network of Government of Rwanda (Obiodu (2013)).

Table 1. Mobile WiMax Projects in Russia

\begin{tabular}{|c|c|c|c|}
\hline Brand & Region & $\begin{array}{l}\text { Frequen- } \\
\text { cy Band }\end{array}$ & Launch dates \\
\hline $\begin{array}{l}\text { Yota } \\
\text { (http://www.yota.ru) }\end{array}$ & $\begin{array}{l}\text { Moscow, } \\
\text { St. Petersburg, Ufa, } \\
\text { Sochi and Krasnodar }\end{array}$ & $\begin{array}{l}2.5-2.7 \\
\mathrm{GHz}\end{array}$ & $\begin{array}{l}\text { April 1, } 2009 \text { - for legal enti- } \\
\text { ties \& June 1, } 2009 \text { - for } \\
\text { individuals }\end{array}$ \\
\hline $\begin{array}{l}\text { COMSTAR } \\
\text { (http://www.comstar.ru) }\end{array}$ & Moscow & $\begin{array}{l}2.5-2.7 \\
\mathrm{GHz}\end{array}$ & $\begin{array}{l}15 \text { January, } 2009 \text { for testing \& } \\
\text { May, } 2009 \text { commercial launch } \\
\text { (J'son \& Partners (2009)). }\end{array}$ \\
\hline $\begin{array}{l}\text { Synterra } \\
\text { (www.synterra.ru) }\end{array}$ & $\begin{array}{l}\text { Moscow Region } \\
\text { (Aprelevka) }\end{array}$ & $\begin{array}{l}2.5-2.7 \\
\mathrm{GHz}\end{array}$ & $\begin{array}{l}\text { April, } 2006 \text { - for business } \\
\text { users (J'son \& Partners } \\
\text { (2009)), Tele-Geography } \\
\text { (2006) }\end{array}$ \\
\hline $\begin{array}{l}\text { Wi-Te } \\
\text { (http://www.wite.ru/) }\end{array}$ & $\begin{array}{l}\text { Central, Siberian, } \\
\text { Volga, Southern, } \\
\text { Ural and Far-Eastern } \\
\text { Federal Districts }\end{array}$ & $\begin{array}{l}2.5-2.7 \\
\mathrm{GHz}\end{array}$ & $\begin{array}{l}\text { June } 2009 \text { in Kemerovo City. } \\
\text { (ITNews (2009)). }\end{array}$ \\
\hline $\begin{array}{l}\text { Freshtel } \\
\text { (http://www.freshtel.ru) }\end{array}$ & $\begin{array}{l}\text { Central and South- } \\
\text { ern Federal } \\
\text { Districts } \\
\end{array}$ & $3.5 \mathrm{GHz}$ & $\begin{array}{l}\text { October } 2009 \text { (J'son \& Part- } \\
\text { ners (2009) }\end{array}$ \\
\hline $\begin{array}{l}\text { Enforta } \\
\text { (http://en.enforta.ru/tec } \\
\text { hnology/) }\end{array}$ & $\begin{array}{l}\text { Moscow and St } \\
\text { Petersburg + other } \\
\text { (Total number is } 93 \\
\text { cities) }\end{array}$ & $\begin{array}{l}2.5 \mathrm{GHz} \\
3.5 \mathrm{GHz} \\
\text { and } \\
5.2 \mathrm{GHz}\end{array}$ & $\begin{array}{l}\text { January } 2005 \\
\text { (http://en.enforta.ru/technolog } \\
\text { y/) }\end{array}$ \\
\hline
\end{tabular}

Source: J'son \& Partners Consulting.

Keeping in view, high economic importance of a collaborative business model of Yota, this research paper is an attempt to integrate facts \& figures of the collaborative model of Yota before it disappear from the business scene of modern era which is not friendly to collaborative business model. These facts and figures are taken mainly from the website of Yota, Internet and other sources of English language. These facts and figures are then integrated and presented in chronological manner under the seven sections. These sections are (i) current achievements of Yota, (ii) reach of Yota in terms of geographical area, (iii) network of Yota and its technology vendors, (iv) services of Yota along with tariff models, (v) expansion plan for future, (vi) strategies for survival in a highly competitive Russian telecom market, and (vii) recent developments where in Yota may cease to exist. A section of introduction and research methodology is also included in the research paper. 
Singh, N. P., Kaushik, M.: Strategies of Yota (Scartel) - 4G Operator in Russian...

\section{Research Methodology}

The research methodology adopted in this article is exploratory in nature and is referred/ defined as Grounded Theory 2.0, a variation from the original grounded theory (Singh (2013)). It is based on mainly secondary data collected and collated from various secondary sources. The data collection and analysis was conducted during November 2011 to September 2013. The main sources of data were the website of Yota, website of WiMAX technologies, web sites of LTE based network operators and websites of other WiMAX Technology based mobile network operators. Other sources of data include the press releases in newpapers about Yota, articles on the subject by academia mainly available on Internet, reports of various marketing \& research agencies and websites of the companies having interest in 4G technologies, blogs of individuals etc. The data is basically analyzed for specific achievement and events in relation to $4 G$ technologies in Russian Federation, and Yota in particular. The major emphasis on data analysis was on company's achievement, expansion plans, tariff models \& strategies for survival in a highly competitive telecom market which does support collaborative business models.

\section{Yota Ownership, Achievements, Agreements, Networks \& Services}

\subsection{Yota Ownership}

Scartel is $74.9 \%$ owned by Telconet Capital Limited Partnership, a privately owned investment fund, with the remaining $25.1 \%$ stake held by the government's Russian Technologies State Corporation. It is reported in TeleGeography (2012d) that Telecominvest, which is majority-owned by billionaire Alisher Usmanov would own Yota 100\% and MegaFon 50\%. The deal was finalized by Federal Antimonopoly Service (FAS) on $15^{\text {th }}$ June 2012. It was also reported by Interfax.com (2012). Ablott (2012b) reported that 82 percent of Yota will be owned by Usmanov's telecoms investment vehicle AF Telecom with the remainder $18 \%$ will be held by Scartel's current shareholders, Telconet Capital and state-backed Russian Technologies.

\subsection{Achievements of Yota}

This section presents achievements of Yota since November 2008. The achievements are in terms of (i) growth of the subscribers base including expansion in geographical reach, (ii) achieving breakeven point, (iii) awards of excellence, (iv) geographical coverage (v) End user devices, (vi) missing lines. 
Singh, N. P., Kaushik, M.: Strategies of Yota (Scartel) - 4G Operator in Russian...

i. Subscriber Base: The statistics presented here is of customers who are using WiMAX technology and from the five cities of Yota's operations. The subscribers statistics compiled from different sources are presented in Table 2. According to one estimate it has reached the figure of 1 million (5\% of the population of five cities of its operation) customers. During its initial days of operation, Yota was adding 2000+ customers every day. The subscriber's base of Yota is still growing at the similar pace. For any newcomers with no experience of telecom business, it is extra ordinary growth.

Table 2. Number of $4 G$ Internet Subscribers of Yota

\begin{tabular}{|c|c|c|c|}
\hline Month Year & $\begin{array}{l}\text { No of Sub- } \\
\text { scribers }\end{array}$ & Geographical Area & Source \\
\hline $\begin{array}{l}\text { October, } \\
2009\end{array}$ & 200,000 & MSUSK* & Yota (2009) \\
\hline $\begin{array}{l}\text { December, } \\
2009\end{array}$ & 350,000 & MSUSK* $^{*}$ & BWA Research (2011) \\
\hline March, 2010 & 380,000 & MSUSK* & Economist (2010) \\
\hline August, 2010 & 600,000 & MSUSK* & Economist (2010) \\
\hline $\begin{array}{l}\text { October } \\
2010\end{array}$ & 682,000 & $\begin{array}{lr}\text { Novosibirsk, } & \text { Sa- } \\
\text { mara, Vladivostok, } \\
\text { Kazan, } \quad \text { and } \\
\text { MSUSK* }\end{array}$ & $\begin{array}{l}\text { http://cellstores.cell- } \\
\text { partners.com/store/p/2729- } \\
\text { Russia-Yota-5-Refill.aspx }\end{array}$ \\
\hline $\begin{array}{l}\text { November, } \\
2010\end{array}$ & 700,000 & MSUSK* $^{*}$ & Lennighan (2010) \\
\hline $\begin{array}{l}\text { December } \\
2010\end{array}$ & $\begin{array}{l}700,000 \\
778,000\end{array}$ & MSUSK* $^{*}$ & $\begin{array}{l}\text { Dobardziev and Girvolas } \\
\text { (2010). } \\
\text { BWA Research (2011) }\end{array}$ \\
\hline $\begin{array}{l}\text { September, } \\
2011\end{array}$ & $\begin{array}{l}1000,000 \\
1,034,000\end{array}$ & MSUSK* $^{*}$ & $\begin{array}{l}\text { Shaw (2011) } \\
\text { BWA Research (2011) }\end{array}$ \\
\hline May, 2012 & 300,000 & $\begin{array}{l}\text { Moscow (Moving } \\
\text { to LTE Technolo- } \\
\text { gy) }\end{array}$ & $\begin{array}{l}\text { Prime Business News } \\
\text { Agency }(2012)\end{array}$ \\
\hline August, 2013 & 648,000 & $\begin{array}{l}\text { Business and } \\
\text { Private customers } \\
\text { for its LTE net- } \\
\text { work. }\end{array}$ & Morris (2013) \\
\hline
\end{tabular}

Source: Author

ii. Breakeven: Yota started its commercial operations in Moscow \& Saint Petersburg on June 1, 2009 and in Ufa on October 12, 2009. It was reported that company has achieved breakeven point in five months of operations. Overall volume of data transferred through the Yota network in all three cities in September amounted to 1848 TB (Yota (2009)). Its 
Singh, N. P., Kaushik, M.: Strategies of Yota (Scartel) - 4G Operator in Russian...

other achievements on this front include a customer base of 600,000, half-year revenue of $\$ 66$ million and $80 \%$ market awareness in Russia. It is achieved in just 14 months of its launching of services (Yota (2010a)).

iii. Yota Awards: Yota have received many awards for excellence (http://www.yota.ru/en/). Some of these were Google Russia award (2009), global telecoms business innovation awards (2009), global mobile awards (2009), more than 500 press coverage, PR Week award (2011) (Yota (2010a)).

iv. Geographical Coverage: It had started its operations in Moscow and St. Petersburg. Its net coverage in Moscow, St. Petersburg and Ufa was over $90 \%$ and it was increasing. In the meanwhile, Yota has expanded its LTE/ WiMAX service to Vyborg, Serpukhow, Ryazan, Naberezhnye Chelny, Tolyatti, Novosibirsk, Samara, Volgograd, Rostov-on-Don, Ekaterinburg, Perm, Chelyabinsk, Nizhny Novgorod, and other cities. To mention, as an example Yota had invested USD 20 million in building 147 base stations to cover the entire area of the Kazan city. Yota achieved download speeds of 10 to $30 \mathrm{Mbps}$ during the testing in Kazan (Kazan News (2010)).

It also operates in two cities of Belarus, i.e., Minsk and Grodno and provided internet access at the speed up to $40 \mathrm{Mbps}$ (Tele-Geography (2012c)). It is also active in Peru \& Nicaragua. In Nicaragua, Yota has deployed WiMAX network in record breaking time. Intel and Samsung were the strategic partners of Yota in Nicaragua (PRNewswire (2009)). By 2012, Yota services were available in 180 Russian cities with a population of more than 100,000 .

v. End User Devices: End User has to acquire a device to receive telecom services. The Mobile WiMAX devices include 4G USB modems, 4G Express cards, 4G phone and laptops \& notebooks with a built-in mobile WiMAX module. Yota had introduced dongles (4G USB-Modem Samsung SWC-U200, 4G Express card Samsung SWC-E100), Smartphones, portable desktop modem, business gateways and 50 laptops(WiMAX Forum (2009). Yota provided multiuser devices and mobile WiMAXMi-Fi Center for companies.

vi. Missing Lines: November, 2009, Yota planned to start commercial operation in Sochi and Krasnodar and to launch operation in 15 more Russian cities in 2010 (Yota (2010b). It has started operations in Sochi \& Krasnodar but not in additional 15 cities as per its plan. 
Singh, N. P., Kaushik, M.: Strategies of Yota (Scartel) - 4G Operator in Russian...

\subsection{Yota Agreements}

Mobile TeleSystems (MTS), MegaFon, VimpelCom and Rostelecom have agreed to create a joint venture to develop $4 G$ network in Russia on the basis of Yota's initial 4G infrastructure at the initiative of the government during 2011(Razumovskaya (2011)). Experts said that if it comes true, it will lower the capital and operating expenses in a country with vast geographical boundaries for all operators but its success was doubted. Brief on individual deals is summarized in the following.

Yota has signed an agreement with Rostelecom (which acquired SkyLink and Svyazinvest). Agreement will allow full use of each other's telecommunications infrastructures with a view to accelerate growth of $4 G$ services to Russian citizens (Press Release (2011) and Anderson (2011)).

Similar deal was signed with MegaFon (Sujit (2011)).Yota and MegaFon will jointly develop 4G LTE network as per the agreement (Luna (2011)). Yota will install its own LTE-equipment on the base stations of MegaFon in cities, where the company did not have its own infrastructure. For that, the company is to pay a commission to the operator. The size of the commission will depend on the amount of provided services (Marchmont New (2011)).

\subsection{Yota Network}

The countries with huge markets like India are rolling out 3G mobile networks, while others have moved to 4G Technologies such as LTE, HSPA+, and WiMAX but not with 100 Mbps. Yota, a start-up had built a 4G network from scratch, burying $3,000 \mathrm{~km}$ (1,864 miles) of fibre-optic cables to connect its wireless base stations with a capacity of $180 \mathrm{Gbit} / \mathrm{s}$. All of Yota's base stations in dense urban areas (around 500) are connected with fiber, and each had a backhaul link capacity of $200 \mathrm{Mbit} / \mathrm{s}$. Its vendor is Cisco for fiber backhaul. The network operates under the standard IEEE 802.16e-2005 with high frequency 2.5-2.7 GHz spectrum band.

In less dense areas, microwave backhaul equipments from DragonWave Inc were installed (Maistre (2009)). Users can connect to the internet via smartphones, laptops and tablets at a speed which is at least as fast as fixedline cable modem which is $6.8 \mathrm{Mbps}$ in United Kingdom (Shaw (2011)). Its network supported more than 51 models of laptop, 1 WiMax /GSM Smartphone, 2 laptop dongles, 2 desktop modems with Wi-Fi (Paolini (2010)). The other devices supported by the network of Yota are listed by Klimanov (2010). Yota had also decided to depend on a single source for its WiMAX radio access equipment (RAN), i.e., Samsung Electronics Co. Ltd (Maistre (2009)). 
Singh, N. P., Kaushik, M.: Strategies of Yota (Scartel) - 4G Operator in Russian...

Yota Networked with Huawei and announced the world's first test LTEAdvanced network with Carrier Aggregation in Moscow in October 2012 achieving downlink peak speeds of $300 \mathrm{Mbps}$. Yota also expected that LTEAdvanced commercial devices will be available in the first half of 2013 (4G Americas (2013)).

Network Business Model: Yota's business model is similar to USA's Clearwire where the wholesale network owner retains a retail business that competes equally with other retail brands (Higginbotham (2011)). If the main stakeholders take up the option to buy Yota after 2014, the model will become a type of network sharing agreement, with Yota remaining as the manager of the network. The model is referred as wholesale operator's collaborative model.

The Difference: The Yota plan is different from other wholesale players or normal MVNO business model. In other countries, wholesale players are building their networks in anticipation that large number of operators will use their networks. However, there is no guarantee that they will use it. For Examples: in USA, there is no guarantee that AT\&T, Verizon, T-Mobile, or any other operator will use LightSquared's network. In Russia, Yota has assurance that it will have at least four tenants on its network, and if the Yota retail brand remains, this will be increased to five. In addition to the benefit to Yota, this mechanism will significantly reduce the cost of rolling out a nationwide LTE network in Russia. It may have capacity constraints, particularly in dense, urban areas but can be taken care of by adding more capacities to the networks (Obiodu and Hartley (2011)). The other operators who had presence in Russia have criticized the agreement because they are excluded from the agreement (IDC (2011)).

\subsection{Yota Services}

The services of the Yota include (i) Yota -4G Internet, (ii) Yota- Music, (iii) Yota-Money, (iv) Yota- Video, and (v) Yota - Yap-Yap.

\section{Expansion / Future Plans of Yota and other Operators}

Yota planned to expand its reach in local markets as well overseas markets specifically in developing countries. Yota cited four reasons to expand in to developing countries. These were (i) the governments in developing countries are less worried about making money from selling radio spectrum but more concerned about getting wireless networks built to foster growth, (ii) the local market is overcrowded with too many players, (iii) the consumers base is big in developing countries and $4 G$ technologies penetration is less, and (iv) less 
competition (may not be the case in all developing countries). As a part of its overseas expansion policies it was up and running in Nicaragua. It had also launched its service in Belarus. It was planning to launch its services in Peru (Economist (2010)). It was also reported that it had planned in past to tie up with MTNL, a network operator operating in Delhi \& Mumbai in India for 4G services but not much was reported about the success (Kapoor (2009)). Later on, it was reported that Yota considered selling its Belarus unit to concentrate more at home front (Tele-Geography (2012a)).

In Russian markets, Yota planned to roll out its 4G services to 180 Russian cities by autumn 2012. It will expand its customer base from its current one million 4G users to a potential 70 million users as reported by Shaw (2011). It will put Yota in the league of Clearwire in the US and TeliaSonera in Scandinavia. It was mentioned by Razumovskaya (2011) that Scartel committed to keep investing in network construction and LTE services will be available in Russia as early as this year, with the network expanding to 180 cities by 2014.

Yota was deploying FD-LTE networks in selected Russian cities alongside its WiMax networks. On May 21, 2010 Yota reported in Russian language on its website that it has plan to invest $\$ 100$ million in 2010 for deployment of new LTE networks in five Russian cities, including Kazan (Kazan-147 cell towers for 1 million subscribers, developed in two months at a cost of \$20 million against the plan of \$30-40 million (Constantinescu (2010), Marchmont News (2010)), and planned to repeat it in Novosibirsk, and Samara. Yota's intention was to launch LTE networks in the first five cities in 2010 and in Moscow and St. Petersburg by the end of 2011. However, it could launch its commercial LTE network in Moscow on May 15, 2012.

Yota decided that future networks will be built using LTE technology and it will continue to develop and support WiMAX infrastructure in the regions where WiMAX has already been deployed, including Moscow, St. Petersburg, Ufa, Sochi, and Krasnodar. Yota planned to more than double the number of WiMAX base stations in Moscow, even as it planned to install LTE networks in Moscow and St. Petersburg by the end of 2011. Yota strategy was to support WiMAX in its existing markets and planned to operate WiMAX and LTE networks in parallel in Moscow and St. Petersburg (Ayvazian (2010)).

The estimated US\$2 billion was needed for building LTE networks. It will be financed by Russian banks, state-owned Russian Technologies and private equity firm Telconet Capital. Even with its complex set of unpaired spectrum holdings in the $2.5 \mathrm{GHz}$ and $2.7 \mathrm{GHz}$ bands and the arcane rules governing them, Yota is likely to end up with a mixture of TDD and FDD networks and more than $50 \mathrm{MHz}$ of capacity in most markets and nearly national coverage. This will position the Russian wholesale $4 G$ network provider as a unique roaming bridge between the LTE FDD (Frequency Division Duplex) networks 
Singh, N. P., Kaushik, M.: Strategies of Yota (Scartel) - 4G Operator in Russian...

developing in Europe and the LTE TDD (Time Division Duplex) networks being deployed by China Mobile and India's BWA licensees (Ayvazian (2011) and Maistre (2011)).

Yota, Rostelecom, and Russia's $3 G$ operators have all announced their interest and intent to deploy LTE networks in the near future (Maravedis (2010)). Rostelecom, its subsidiary Sibirtelecom, and Vainakh telecom have been granted permission by Russian Ministry of Defense to commence the deployment of LTE network. As per the term of licenses, Rostelecom is asked to build and launch 4G networks within 18 months using Russian-made equipment in their respective areas (Russia (2011b)).

\section{Strategies of Yota \& their Analysis}

i. Tariff Strategy: It had built its core and fixed backhaul network. It had planned its expansion strategies via a strategic partnership with other biggies in Russian Telecom market. Its equipment partners are Cisco, DragonWave, Samsung Electronics Co. Limited. Its data usage strategy is "All you can eat". The data usage strategy is supported with its tariff model of $\$ 28 /$ month with no restrictions on streaming of videos and data download volumes. The average cost of DSL line connectivity in Russia is about $\$ 13 /$ month with a limit on data download volumes.

"The strategy is based on the speed, quality with no download restrictions but for more money with affordability".

Key Achievements of the strategy: Select user's average monthly download reaching 10.3 gigabytes over wireless access connections of up to $10 \mathrm{Mbit} / \mathrm{s}$. One heavy video user downloaded 1.82 terabytes of data in one month. At the rate of $\$ 28$ per month with 1 million customers its monthly revenue is $\$ 28$ million per month. It is equivalent to $\$ 336$ million per year. It is still a small part of fixed broadband Russian market which was $\$ 1.5$ billion in 2008 .

ii. Customer Premises Equipment (CPE) Strategy: Yota reported that more than 60 notebook models available in Russia have embedded 802.16 e capabilities and can be hooked to Yota's network. It has provided LTE modem at the time of switching from WiMAX to LTE as a part of its CPE strategy as well as customer relation strategy (Litteskylark (2012)).

iii. Assured Tenancy on Network: The deal with rival networks Beeline, Megafon, MTS and Rostelecom to roll out its $4 G$ system across the country's 180 cities, made it available to more than 70 million people 
Singh, N. P., Kaushik, M.: Strategies of Yota (Scartel) - 4G Operator in Russian...

by 2014 with assurance of two tenants on its network (Yota (2011)). However, there is need to devise a strategy to beat pressure on revenue \& margins of future LTE partners (Telecompaper (2011b)).

iv. Competition: It will soon have competition from newcomer Freshtel, which will have initial access to $\$ 300$ million of capital and have similar expansion strategies (FreshTel News (2009)). Donegan (2009) mentioned that Icon Private Equity, will invest \$200 million in the new WiMax Russian operator. The new operator has a license in the 3.5 $\mathrm{GHz}$ frequency band and will operate under the brand name Freshtel. The $\$ 100$ million will come by way of a loan from Chinese financial institutions.Malakhov and Balashova (2010) mentioned that Freshtel will offer the similar services at a cost of \$13 per month which is at par with 3G tariff. Yota's competitors include Comstar (Cellular News (2009)), WiTe (Maximus (2009)), Enforta with its footprint in 93 cities (Enforta News (2009)), Osnova Telecom, an LTE licensee (Iladi (2010)), and Synterra (Russia (2011a)). Though Synterra and other are operating in different areas from Yota at present with not much overlap but Yota need to devise a competition strategy for future success.

v. Visionary Initiatives/ Moves: Operators in Nicaragua market offer $3 G$ mobile data subscription at \$60 a month for a 3G (third generation) mobile data subscription at a speed of $1 \mathrm{Mbps}$ (bits per second) with a limit of 2GB download (Sayer (2009)). Yota's existing subscription rate of US\$28, or less, or more, a month for unlimited data with no speed cap will be good value to Nicaraguans. The similar business model can be repeated in other markets if feasible.

vi. Shift in Technology: Yota management is not to adopt one technology but select a better promising 4G technology (LTE in the case) as and when it is available \& cost effective. Yota has chosen, Nokia and Samsung for LTE standard (Reuters (2010)). Both the technologies can use the same frequency of spectrum. The dispute over the frequencies is solved for Yota but the problem of technological neutrality remains unresolved (Russian News (2011)).

vii. Business Model: The core of Yota Business model is sharing of infrastructure with other operators. It will be more cost effective to all players in Russian market which has huge geographical spread in comparison to the thickly populated Indian and Chinese telecom markets. It will create a space for companies to concentrate more on products, services and also to make telecom services more environmental friendly (Global Telecom Business (2011)). Secondly, its business models to revolve around "elementary speed units", such as 
Singh, N. P., Kaushik, M.: Strategies of Yota (Scartel) - 4G Operator in Russian...

"megabit per second" rather the amount. It will make the whole business more sustainable in its view (Zaripova (2012)).

viii. Outsourcing of Business Activities: Yota has been working with UCMS Group Russia for over 18 months since mid 2010. Yota has outsourced Payroll and HR processing services including the preparation and submission of reports to the authorities to UCMS Group (News (2012)). Yota has signed a 10-year agreement with Linxdatacenterfor providing tier 3 datacenter solutions to Yota in Saint Petersburg (http://linxtelecom.com/node/509).

ix. Working more closely with other Mobile Network Service Providers: Yota has recently signed an agreement with Rostelecom based on Virtual Mobile Network Operator (MVNO) model (Rostelecom (2012)). Yota has announced the launch of its LTE network in Novosibirsk. MegaFon under an MVNO deal will be service provider (TeleGeography (2012b)). However, Russian LTE MVNO models are likely to be short lived (Cellular news (2012)). It is reported that Yota and MegaFon are considering the merger \& filed a request with Federal Antimonopoly Service (FAS) (East-west digital news (2012)).

x. New Owner and issues: Rostelecom has lodged a complaint with Moscow's Commercial Court in September 2012 against Yota . Yota is obliged to offer its rival access to its in-deployment LTE network via a mobile virtual network operator (MVNO) agreement (Telegeography (2013)). Russia's Rostelecom has announced an MVNO deal with LTE operator Scartel (Yota) as reported by Tele-geography. Under the terms of the contract, testing was expected to commence in Moscow on 1 July 2012, with a commercial launch mooted for September 1, 2012. The deal gives Rostelecom access to Yota's frequencies in the $2500 \mathrm{MHz}-2530 \mathrm{MHz}$ and $2620 \mathrm{MHz}-2650 \mathrm{MHz}$ spectrum bands (Ablott (2012a)).

\section{Recent Development}

In the recent past, it is reported that MegaFon, Russia's second-biggest mobile operator is buying $100 \%$ of Yota for $\$ 1.18$ billion (€882.5 million) (Morris (2013)). MegaFon will gain an edge in Russia's nascent market for 4G mobile services. Russia's Federal Anti-monopoly Service has granted permission to MegaFon to buy 100 per cent of Scartel (telecoms.com (2013)). TeliaSonera (a share holder in Megafon) had analyzed the deal and concluded that acquisition of Scartel (Yota) would strategically attractive and value enhancing for MegaFon (Hibberd (2013)). The reason for buyout could be in the mind of promoters that it will be tough for Yota to compete in LTE Russian markets as 
Singh, N. P., Kaushik, M.: Strategies of Yota (Scartel) - 4G Operator in Russian...

predicted by Dobardziev and Girvolas (2010). Earlier it was reported that Russian mobile giant MegaFon and WiMAX-turned-Long Term Evolution (LTE) operator Scartel (Yota) have completed the merger of their telecoms assets (Tele-Geography (2012d)). This will be a major setback to Yota Business Model (CEE Insight (2012)).

\section{Concluding Remarks:}

Yota, a Russian WiMAX-turned-LTE player, announced a wholesale network deal that will make it the key LTE network provider in Russia. Its LTE network will cover 200 cities across Russia covering 70 million people (Ruble (2012)).

Lightsquared, USA, also recently announced a wholesale model for a nationwide wireless broadband network in the US. While these are both extremely ambitious plans, if they succeed, the future of the mobile industry will be considerably different from what it is today. It can be said that Yota, Lightsquared and TeliaSonera will shape the future of mobile services in the world. Government of Kenya has also tried to emulate Yota Model but with a bleak outlook (Singh (2013)).

The Yota model was different from Lightsquared, USA with a guaranteed business from four big operators in Russia still its success depends on many factors or behavior of market, and policy changes. Some of the happenings as mentioned below are not in favor of Yota Business Model

(i) Few functionaries of the Russian government think it has too much radio spectrum, and want to give this radio spectrum to other operator. The country's telecom regulator recently cancelled some licenses, a decision that Yota is fighting in court.

(ii) Yota is certainly ambitious. It dreams to establish a global brand. However, alone Nicaragua will not help. In past global brand of Russian companies is a rarity for Russia. If it happen it will be highly beneficial in creating Russian MNCs or global brand in future.

(iii) There is a criticism by four big carriers in Russian Federation on the following two accounts, i.e. (a) the amount of the valuation of Yota as $\$ 1$ billion, (b) it may hurt small players in the market. The success of the Yota model had to wait (Gabriel (2011b)).

(iv) Yota is not wedded to a single technology. It had no inhibition in switching from WiMax, to LTE (Belic (2010)). It is a positive sign in its strategies. Another positive sign is simple business model of Yota. LTE price might have decreased by $60 \%$ in the market by 2016 (Sa- 
Singh, N. P., Kaushik, M.: Strategies of Yota (Scartel) - 4G Operator in Russian...

hota (2011)). The 8 years business experience of Yota by 2016 will help it to compete in the LTE based broadband market.

(v) Major Event: Russia has gone back to the tried and tested method of awarding spectrum to multiple operators wherein each build their own LTE networks. MTS, Vimpelcom, Megafon, and Rostelecom were all awarded free licenses to provide nationwide LTE services by 2019 , with the condition that they must meet annual investment targets of RUB15bn (\$459m) (Obiodu (2013)).

(vi) Another missing link in the strategies is no investment in research and development by Yota. It has made Yota completely dependent on others for new technologies as and when needed.

(vii) Megafon plan to buy Yota for $\$ 1.2$ billion. It will be an end to excellent resource sharing business model.

In the end it can be inferred that Yota Business model will come to an end very soon due to above listed reasons. The big four telecom operators will write the destiny of $4 \mathrm{G}$ telecom markets in Russia

\section{Points for Further Research}

There is a need to test following hypotheses in future.

(i) A business model in telecom industry which is cost effective, environmental friendly and might have saved the earth resources in future will not survive unless it makes more business sense to the stakeholders.

(ii) Even, if all countries adopt such collaborative strategies which generate saving of many natural resources on the earth and these saving may be solution to the recent economic crises to some extent will not be successful unless it clearly defines winners \& losers in the game.

(iii) Company of a country/society with so many inventions to its credit is planning to run faster to win the race with complete dependency on external technological resources looks somewhat a week strategy. Yota model may be a learning lesson to companies.

(iv) Big size (both in term of money \& manpower) is needed to sustain the business in a competitive \& growing markets for the longer duration.

(v) Kenya is building a single LTE network and plan to support many mobile operators via wholesale agreements in deploying 4G net- 
Singh, N. P., Kaushik, M.: Strategies of Yota (Scartel) - 4G Operator in Russian...

works (Gabriel (2011a)). It may be successful because of four reasons. These are (a) less competition among buyers, (b) less competition among provider side, (c) very basic structures of the needs of the citizens, and (c) data transfer needs may not be as in case of developed economies. It may also go Yota's way. There is a need to analyze.

(vi) There is a need to research the negative side of telecom business in the context of environment and positive side of business models such as Yota.

\section{References}

Ablott, M. (2012). Rostelecom to launch LTE MVNO. April, 13th. Retrieved from http://www.mobileworldlive.com/rostelecom-to-launch-lte-mvno 2013 Mar 12.

Ablott, M. (2012). Usmanov inks MegaFon/Scartel merger. July, 12th. Retrieved from http://www.mobileworldlive.com/usmanov-inks-megafonscartel-merger 2013 Mar 12.

Anderson, R. (2011). Yota and Rostelecom partner for LTE network. December, 8th. Retrieved from http://www.capacitymagazine.com/Article/ 2946193/Home/Yotaand-Rostelecom-partner-for-LTE-network.html 2011 Dec 9.

Ayvazian, B. (2010). Yota: WiMax + LTE for Russia. May, 26th. Retrieved from http://www.lightreading.com/document.asp?doc_id=192494 2011 Dec 8.

Ayvazian, B. (2011). Yota Moves Forward With LTE. March, 7th. Retrieved from http://www.lightreading.com/document.asp?doc_id=2053072011 Dec 9.

Belic, D. (2010). Yota-to-abandon-WiMAX-in-favor-of-LTE.html. May, 26th. Retrieved from http://www.intomobile.com/2010/05/26/russias-yota-to-abandon-wimax-infavor-of-Ite 2012 Feb 12.

BWA Research, LTE \& WiMAX OPERATORS DATABASE: Yota (WiMAX) (2011) Retrieved

http://www.4gcounts.com/WiMAXWebSite/ViewProfile.aspx?Sample=1 2010 Dec 13.

CEE Insight, MegaFon acquires LTE 4G technology (2012) April, 27th. Retrieved from http://ceeinsight.net/article/237/megafon-acquires-Ite-4g-technology 2012 May 12.

Cellular News, Comstar to Launch Moscow WiMAX Network in May (2009) April, 30th. Retrieved from http://www.cellular-news.com/story/37272.php 2011 Dec 8.

Cellular News, Fitch: Russian LTE MVNO Advantages Likely to Be Short-Lived (2012) September, 4th. Retrieved from http://www.cellular-news.com/story/56206.php 2013 Mar 13.

Constantinescu, S. (2010). Yota dumps WiMAX, launches Russia's first LTE network: 147 cell towers cover over 1 million people. September, 5th. Retrieved from http://www.intomobile.com/2010/09/05/yota-dumps-wimax-launches-russias-firstIte-network-147-cell-towers-cover-over-1-million-people 2010 Dec 12. 
Singh, N. P., Kaushik, M.: Strategies of Yota (Scartel) - 4G Operator in Russian...

Dobardziev, A., \& Girvolas, J. (2010). Yota expansion must be carefully managed. December, 22nd. Retrieved from http://www.telecomsemea.net/content/yotaexpansion-must-be-carefully-managed 2013 Mar 23.

Donegan, M. (2009). Huawei Seals Russian WiMax Deal. June, 16th. Retrieved from http://www.lightreading.com/blog.asp?blog_sectionid=414\&doc_id=178056 2011 Dec 1.

East-West Digital News, MegaFon and Yota consider merger (2012) May, 3rd. Retrieved from http://www.ewdn.com/2012/05/03/megafon-and-yota-considermerger 2012 May 12.

-Economist. (2010). 4G mobile networks- From Russia with bandwidth. August, 19th. Retrieved from http://www.economist.com/node/16846752 2011 Nov 11.

Enforta News, Enforta To Add 25 Cities to It's Russian WiMAX Network in 2010 Russia's Largest Regional WiMAX Operator Expands its Service Area to 93 Cities (2009) October, 26th. Retrieved from http://en.enforta.ru/company/newseng/newseng_262.html 2011 Dec 10.

FreshTel News, Freshtel - First 4G Network In Ukraine (2009) Retrieved from http://freshtel.ua/uploads/media/FreshTelPress-releaseENG_FIN. doc 2011 Dec 8.

Gabriel, C. (2011). Kenya plans single wholesale LTE network. August, 30th. Retrieved from http://www.rethink-wireless.com/2011/08/30/kenya-plans-singlewholesale-Ite-network.htm 2012 Feb 29.

Gabriel, C. (2011). Russia LTE plan hits another hurdle. August, 31st. Retrieved from http://www.rethink-wireless.com/2011/08/31/russia-Ite-plan-hits-hurdle.htm 2012 Feb 29.

-Global Telecom Business. (2011). CEO tells how Yota will bring Russian LTE operators together. March, 21st. Retrieved from http://www.globaltelecomsbusiness.com/Article/2791398/Interviews/25239/CEOtells-how-Yota-will-bring-Russian-LTE-operators-together.html 2011 Dec 11.

Hibberd, M. (2013). TeliaSonera backs Megafon's Yota acquisition. August, 8th. Retrieved from http://www.telecoms.com/169272/teliasonera-backs-megafons-yotaacquisition 2013 Sep 10.

Higginbotham, S. (2011). Clearwire's LTE plans reinvent the mobile operator. August, 5th. Retrieved from http://gigaom.com/broadband/clearwire-lte 2011 Dec 11.

-IDC. (2011). The Path to 4G in Russia and the United States: A Comparison of Yota and Sprint. Retrieved from http://www.giiresearch.com/report/id212601-path-4grussia-united-states-comparison-yota.html 2011 Dec 3.

Iladi, E. (2010). III Neo-Soviet Winds Blowing in Russia's Telecom Market. July, 27th. Retrieved from http://larussophobe.wordpress.com/2010/07/27/op-ed-ill-windsof-neo-soviet-nationalization-blowing-in-russia 2011 Dec 10.

Interfax.com (1012). Usmanov, Russian Technologies could merge Megafon, Scartel assets - paper (2013) April, 10th. Retrieved from http://www.interfax.com/newsinf.asp?pg=7\&id=323005 2013 Mar 12.

-IT News. (2009). WITE declares start of a network of broadband wireless access on company Huawei equipment. June, 10th. Retrieved from http://blog4it.net/witedeclares-start-of-a-network-of-broadband-wireless-access-on-company-huaweiequipment 2011 Dec 1.

-J'son \& Partners. (2009). Market Watch- Overview of the mobile WiMAX market in Russia and worldwide. August. Retrieved from 
Singh, N. P., Kaushik, M.: Strategies of Yota (Scartel) - 4G Operator in Russian...

http://www.json.ru/files/news/mWiMAX_\%20Market_Watch_1H09_LOC_ENG.pd f 2011 Nov 12.

Kapoor, A. (2009). Russian Telco Yota To Enter India's Wimax Scene. July, 7th. Retrieved from http://www.watblog.com/2009/07/07/russian-telco-yota-to-enterindias-wimax-scene 2012 Jan 12.

Kazan News, Yota launches LTE in Kazan (2010) August, 10th. Retrieved from http://eng.tatar-inform.ru/news/2010/08/31/31409 2012 May 10.

Klimanov, M. (2010). Yota WiMAX or 4G reality in Moscow. January, 25th. Retrieved from http://www.foxnetwork.ru/index.php/en/component/content/article/65-yotawimax.html 2011 Nov 11.

Lennighan, M. (2010). Russia's Yota seeks partners with spectrum. November, 18th. Retrieved from http://www.totaltele.com/view.aspx?ID=460372 2011 Dec 11.

Litteskylark, (2012). Owner Yota extended exchange of wimax-modem device on the LTE. May, 13th. Retrieved from http://littleskylark.com/blog/owner-yotaextended-exchange-of-wimax-modem-device-on-the-lte 2012 May 16.

Luna, L. (2011). Russia's Yota, MegaFon agree to jointly develop LTE network. December, $\quad 5$ th. Retrieved from http://www.fiercebroadbandwireless.com/story/russias-yota-megafon-agreejointly-develop-Ite-network/2011-12-05 2011 Dec 8.

Maistre, R.L. (2009). Yota: A Model WiMax Startup. November, 9th. Retrieved from http://www.lightreading.com/document.asp?doc_id=184325 2011 Nov 10.

Maistre, R.L. (2011). Russian Ops to Share LTE Network. March, 4th. Retrieved from http://www.lightreading.com/document.asp?doc_id=205225 2011 Dec 9.

Malakhov, A., \& Balashova, A. (2010). Freshtel to seek boost from small business. March, 23rd. Retrieved from http://www.iconpe.com/?id=pressa_eng \&desc=184 2011 Dec 2.

Maravedis, (2010). Russia Wireless Broadband Summary. September, 2nd. Retrieved from http://lteworld.org/blog/russia-wireless-broadband-summary 2011 Nov 29.

Maximus, (2009). "WITE" launch commercial service of a standard WiMAX 802. 16e network in the city of Kemerovo. Retrieved from http://justamp.blogspot.com/2009/06/wite-launch-commercial-service-of.html 2011 Dec 8.

Marchmont News, Scartel to launch "\$30-\$40m" LTE network in Kazan (2010) May, 28th. Retrieved from http://www.marchmontnews.com/Archive/News/13016.html 2011 Dec 12.

Marchmont News, Yota to lay out LTE network on MegaFon's infrastructure (2011) December, 1st. Retrieved from http://marchmontcapital.com/TechnologyInnovation/Central-regions/18098-Yota-lay-out-LTE-network-MegaFonsinfrastructure.html $2011 \mathrm{Dec} 13$.

Morris, A. (2013). Russia's MegaFon gains LTE edge with \$1. 2B Scartel/Yota purchase. August, 9th. Retrieved from http://www.fiercewireless.com/europe/story/russias-megafon-gains-Ite-edge-12bscartelyota-purchase/2013-08-09 2013 Sep 14.

News, Russia telecoms firms sign agreement with Russian government to build next generation of mobile networks (2011) May, 3rd. Retrieved from http://www.investinrussia.biz/news/russia-telecoms-firms-sign-agreementrussian-government-build-next-generation-mobile-networks-53g6 2011 Dec 3. 
Singh, N. P., Kaushik, M.: Strategies of Yota (Scartel) - 4G Operator in Russian...

News, In 2012, Customers of MegaFon and Yota Will Get Access to 4G Services in Russia (2011) November, 30th. Retrieved from http://english.corp.megafon.ru/news/20111130-1846.html 2011 Dec 3.

News, Stay updated with the latest news from UCMS Group Poland (2012) January, 10th. Retrieved from http://www.ucmsgroup.pl/news/news-post/yota-outsourcespayroll-and-hr-to-ucms-group-russia 2012 Feb 29.

Obiodu, E., \& Hartley, S. (2011). Does Yota's Russian LTE plan validate the wholesale mobile network model. Retrieved from http://ovum.com/2011/03/07/doesyota $\%$ E2\%80\%99s-russian-Ite-plan-validate-the-wholesale-mobile-networkmodel 2011 Dec 8.

Obiodu, E., \& Putcha, S. (2011). Is Russia's national wholesale LTE network unraveling. October, 12th. Retrieved from http://ovum.com/2011/10/12/is-russiasnational-wholesale-lte-network-unraveling/ 2011 Dec 5.

Obiodu, E. (2013). Rwanda's 4G wholesale plan stokes debate between political expediency and commercial principles. June, 19th. Retrieved from http://ovum.com/2013/06/19/rwandas-4g-wholesale-plan-between-commercialprinciples-and-political-expediency 2013 Sep 10.

Paolini, M. (2010). More than one Yota of Difference, White paper. Retrieved from http://www.wimax.com/whitepapers/senza-fili-more-than-one-yota-ofdifference.pdf 2011 Nov 23.

-PR Newswire. (2009). Yota Deployed Mobile WiMAX in Nicaragua in Record-breaking Time. December, 15th. Retrieved from http://www.prnewswire.com/newsreleases/yota-deployed-mobile-wimax-in-nicaragua-in-record-breaking-time79367652.html 2012 May 12.

Prime Business News Agency, Russia's Scartel launches 4G LTE services in Moscow (2012) May, 10th. Retrieved from http://www.1prime.biz/news/0/\%7BA5F33433F89C-486B-AEC6-099F2E9F6288\%7D.uif 2012 May 12.

Press Release, Rostelecom and Yota sign an agreement to jointly develop and utilize wireless 4G networks (2011) December, 2nd. Retrieved from http://www.rustocks.com/index.phtml/Pressreleases/RTKM/1/29113 2011 Dec 9.

Prime Business News Agency, Russia's Scartel launches 4G LTE services in Moscow (2012) May, 10th. Retrieved from http://www.1prime.biz/news/0/\%7BA5F33433F89C-486B-AEC6-099F2E9F6288\%7D.uif 2012 May 12.

Razumovskaya, O. (2011). Mobile Giants to Invest in Yota for 4G. March, 4th. Retrieved from http://www.themoscowtimes.com/business/article/mobile-giants-toinvest-in-yota-for-4g/432052.html 2011 Dec 10.

-Reuters. (2010). Russia's Yota drops WiMax in favour of LTE. May, 22nd. Retrieved from http://petersburgcity.com/news/business/2010/05/22/yota/print.phtml. 2012 Feb 23.

-Rostelecom. (2012). Rostelecom and Yota Sign Agreement to Utilise LTE Network. April, 11th. Retrieved from http://4g-portal.com/rostelecom-and-yota-signagreement-to-utilise-Ite-network 2012 Apr 30.

Ruble, N. (2012). Yota to Expand Presence of LTE Operations in Russia. April, 17th. Retrieved from http://next-generationcommunications.tmcnet.com/topics/nextgen-voice/articles/286573-yota-expandpresence-Ite-operations-russia.htm 2012 Apr 30.

Russia, Synterra taps Gilat for Far East, Siberian broadband connectivity (2011) July, 14th.

Retrieved

from 
Singh, N. P., Kaushik, M.: Strategies of Yota (Scartel) - 4G Operator in Russian...

http://www.telegeography.com/products/commsupdate/articles/2011/07/14/synte rra-taps-gilat-for-far-east-siberian-broadband-connectivity/ 2011 Dec 3.

Russia, Rostelecom given belated clearance for LTE rollout (2011) December, 1st. Retrieved from http://www.telegeography.com/products/commsupdate/articles/2011/12/01/rostel ecom-given-belated-clearance-for-Ite-rollout/ 2011 Dec 5.

Russian News, Yota Solves Frequencies Dispute (2011) April, 13th. Retrieved from http://news.windowstorussia.com/yota-solves-frequencies-dispute.html 2012 Feb 29.

Sahota, D. (2011). LTE mobile broadband pricing set to decline by 60 per cent. December, 19th. Retrieved from http://www.telecoms.com/37958/lte-mobilebroadband-pricing-set-to-decline-by-60-per-cent/?utm_source=rss\&utm_ medium=rss\&utm_campaign=Ite-mobile-broadband-pricing-set-to-decline-by-60-percent 2011 Dec 19.

Sayer, P. (2009). Russian WiMax Operator Eyes GSM Handover, WiMax 2 Testsm. October, 7th. Retrieved from http://www.pcworld.com/businesscenter/article/173258/russian_wimax_operator _eyes_gsm_handover_wimax_2_tests.html 2011 Dec 1.

-Senzafili Consulting. (2010). More than one Yota of difference. Retrieved from http://www.senzafiliconsulting.com/Blog/tabid/64/articleType/ArticleView/articleld /12/More-than-one-Yota-of-difference.aspx 2012 May 12.

Shaw, W. (2011). The way we consume data is about to change forever. Hello, 4G. September, 29th. Retrieved from http://www.wired.co.uk/magazine/archive/2011/10/features/hello-4g?page=all 2011 Nov 21.

Singh, N.P. (2013). Collaborative Model in Telecom Business- Success or Failure. (Unpublished Research paper).

Sujit, G. (2011). Russia's Yota and MegaFon sign deal on LTE network development. December, 1st. Retrieved from http://lteworld.org/news/russia-s-yota-andmegafon-sign-deal-Ite-network-development 2011 Dec 8.

-Telecompaper. (2011). Yota to build wholesale LTE network for Russian operators. March, 3rd. Retrieved from http://www.telecompaper.com/news/yota-to-buildwholesale-Ite-network-for-russian-operators $2011 \mathrm{Dec} 12$.

-Telecompaper. (2011). MTS sees results under pressure from Yota deal. June, 21st. Retrieved from http://www.telecompaper.com/news/mts-sees-results-underpressure-from-yota-deal 2011 Dec 10.

-Telecoms.com. (2013). MegaFon given green light to acquire Scartel. July, 29th. Retrieved from http://www.extensia-Itd.com/articles/megafon-given-green-lightto-acquire-scartel/12580 2013 Sep 10.

-Tele-Geography. (2006). Synterra launches Moscow's first commercial WiMAX service. April, 4th. Retrieved from http://www.telegeography.com/products/commsupdate/articles/2006/04/04/synte rra-launches-moscows-first-commercial-wimax-service/ 2011 Dec 8.

-Tele-Geography. (2012). Russia's Yota rushing to sell Belarusian business, report says. April, 18th. Retrieved from http://www.telegeography.com/products/commsupdate/articles/2012/04/18/russi as-yota-rushing-to-sell-belarusian-business-report-says/ 2012 Apr 24.

-Tele-Geography. (2012). MegaFon launches 4G services via Yota; resolves ownership disputes. April, 24th. Retrieved from 
Singh, N. P., Kaushik, M.: Strategies of Yota (Scartel) - 4G Operator in Russian...

http://www.telegeography.com/products/commsupdate/articles/2012/04/24/mega fon-launches-4g-services-via-yota-resolves-ownership-disputes/ 2012 May 12.

-Tele-Geography. (2012). No day of rest as Yota Bel sets Sunday launch date for LTE. May, 4th. Retrieved from http://www.telegeography.com/products/commsupdate/articles/2012/05/04/noday-of-rest-as-yota-bel-sets-sunday-launch-date-for-Ite/

-Tele-Geography. (2012). MegaFon, Scartel complete asset merger. July, 12th. Retrieved from http://www.telegeography.com/products/commsupdate/articles/2012/07/12/mega fon-scartel-complete-asset-merger/ 2013 Mar 12.

-Tele-Geography. (2013). FAS files case against Yota over LTE discrimination. March, 12th. Retrieved from http://www.telegeography.com/products/commsupdate/articles/2013/03/12/fasfiles-case-against-yota-over-Ite-discrimination/ 2013 Mar 20.

-WiMax Forum. (2009). First Russian Mobile WiMAX Network. Retrieved from http://www.wimaxforum.org/sites/wimaxforum.org/files/document_library/yota.pdf 2011 Dec 8.

-Yota. (2009). Yota Reaches Breakeven. November, 9th. Retrieved from http://www.lightreading.com/document.asp?doc_id=184298 2011 Nov 10.

-Yota. (2010). Creating the world's first 4G telecoms brand. August. Retrieved from http://www.300million.com/_downloads/300million-Yota.pdf 2011 Dec 8.

Yota, (2010). Yota Deploys Most Significant 4G Network to Date 30-08-2010. Retrieved from http://www.yota.ru/en/info/news/details/?ID=246344 2011 Dec 8.

Zaripova, L. (2012). CEO, Yota: "Nobody wants to count megabytes watching a movie". Retrieved from http://kazantimes.com/business/ceo-yota-nobody-wants-to-countmegabytes-watching-a-movie 2012 May 16.

4G Americas, (2013). 3GPP Mobile Broadband. April. Retrieved from http://www.4gamericas.org/UserFiles/file/Tech\%20Stats/2013_Technical_Statisti cs_April.pdf 2013 Jul 10. 